Island Studies Journal, Vol. 10, No. 2, 2015, pp. 163-180

\title{
The Minquiers and Écréhous in spatial context: Contemporary issues and cross perspectives on border islands, reefs and rocks
}

\author{
Christian Fleury \\ ESO (Espaces et Sociétés) Caen, \\ Université de Caen-Normandie, France \\ fleury.cote@wanadoo.fr \\ and \\ Henry Johnson \\ University of Otago, New Zealand \\ henry.johnson@otago.ac.nz
}

\begin{abstract}
The Minquiers and Écréhous reefs are located in different parts of the Gulf of St Malo between the British island of Jersey and the French mainland. As a part of the Bailiwick of Jersey, they are geographically very close to the international sea border between Jersey and France, and have had a history of disputed sovereignty. Due to their respective geographical locations and histories, the Minquiers and Écréhous are important sites for the field of Island Studies because of their existence as "border islands". This article offers a study of these reefs in their spatial context of land and sea, discussing contemporary issues, including fishing, environmentalism and tourism, and offering cross perspectives in terms of their political, economic and cultural connections with Jersey and France. They exist in a context of immense spatial change with substantial tidal ebbs and flows, and between mainlands and historically contested maritime terrains. Such a study helps show how the Minquiers and Écréhous occupy an inbetween space (land, sea and nations), which resulted in international agreements in 2000 that confirmed both the maritime boundary separating France and Jersey, and the areas agreed on as common waters for fishing purposes within Jersey's jurisdiction. In this setting, this paper offers a critical discussion on the nature of "islands inbetween" (including all the Channel Islands), where land and sea are interconnected as a result of nature, politics, historical fishing rights and leisure activities.
\end{abstract}

Keywords: border islands, British Isles, Channel Islands, Écréhous, France, islands inbetween, Jersey, liminality, Minquiers.

(C) 2015 - Institute of Island Studies, University of Prince Edward Island, Canada.

\section{Introduction}

As part of the Bailiwick of Jersey (a British Crown Dependency), ${ }^{1}$ and due to their respective geographical locations and histories, the Minquiers (Le Plateau des Minquiers, or Les Minquiers) and Écréhous (Les Écréhous) are important sites for the field of Island Studies because of their existence as "border islands". Specifically, they are two distinct reefs that

${ }^{1}$ As a jurisdiction originally under the control of a Bailiff, the Bailiwick of Jersey maintains its allegiance to the British Crown, with the Bailiff carrying out ceremonial, political and legal roles. 


\section{Fleury \& H. Johnson}

comprise islets and rocks that are close to the international border between the Bailiwick of Jersey and the Republic of France. This article offers a study of these reefs in their spatial context of land and sea, discussing contemporary issues and offering cross perspectives in terms of the reefs' political, economic and cultural connections with Jersey and France. They exist in a context of immense spatial change with substantial tidal ebbs and flows, and between mainlands and historically contested maritime terrains. Such a study helps show how the Minquiers and Écréhous occupy an inbetween space (land, sea and nations), which resulted in two international agreements in 2000 that confirmed both the maritime boundary separating France and Jersey, and the areas agreed on as common waters for fishing purposes within Jersey's jurisdiction (Agreement, 2000a; b). Both agreements came into force on 1 January 2004, and the latter is usually referred to as the Granville Bay Agreement. In this setting, and as examples of border islands, this paper offers a critical discussion on the nature of "islands inbetween" (including all the Channel Islands) (Baldacchino, 2008), where land and sea are interconnected as a result of politics, historical fishing rights and leisure activities.

The methods used for this research are mixed. One author was born in Granville, which is the nearest French mainland port to the Minquiers, and the other on Jersey, in the Parish of Grouville, which administers that reef. Among them, they have visited one or both of the two reefs under study on various occasions for fishing, tourism or research, and each has engaged in historical and analytical approaches while studying these locations. More specifically, the authors bring cross perspectives to the study, but with a common interest in the field of Island Studies: different nationalities, approaches and fields of expertise. Data has been gained through literature reviews (primary and secondary literature), first-hand experience of visiting the reefs, through a short survey with key informants (e.g., those working in the fishing and tourism industries, as well as those who administer or have property on the reefs). The survey was distributed in Jersey to a small number of people: the two parish authorities that administer the reefs, Jersey Harbours, a residents' group for the Écréhous, and two adventure tourism operators. The purpose of the survey was to gather personal perspectives on how informants perceive the relationship between Jersey and France with the Minquiers and/or Écréhous, and what it means for informants to visit the reefs. Several anonymous quotes from the surveys are included in the article with the objective of showing "insider" perspectives from those who visit one or both of the reefs on a regular basis.

While investigating border islands, the article draws on pertinent theoretical literature that offers ways of comprehending such inbetween space. The notion of "liminality" offers a similar perspective, and Turner's (1977) use of the term is particularly relevant in our analysis in several ways: (1) to show how the Minquiers and Écréhous exist on the edge of one jurisdiction and very close to its border with a nation state; and (2) in connection with the movement of people to these reefs, whether for work or pleasure. With a dual sense of liminality, the Minquiers and Écréhous offer a sense of being inbetween, where these land and marine zones occupy a space on the edge of one jurisdiction and just across the border of another (cf. Ankei, 2013). Hence, the Minquiers and Écréhous are locations within a "space between" (Bhabha, 1994) two broader locations, each of which acts as a political "other" to the other. In this context, as with other political boundaries, "borders institutionalize territoriality and are politically implemented by states" (Godenau, 2012, p. 3). The border separating France and the Bailiwick of Jersey, as defined by a sea boundary close to the reefs under study, helps to reinforce a sense of national territories. However, while the Minquiers and Écréhous are the closest land mass to this border, and have been the subject of much 
contestation over sovereignty and fishing rights for several centuries, they currently exist not only in terms of being close to political borders as "marginal islands" (King, 2009, p. 63) for both France and the Bailiwick of Jersey, but also with a degree of flexible boundaries where access is not necessarily restricted because of nationality. Indeed, this article is unlike some studies on "border management" (Godenau, 2012, p. 3), and more focused on islands as sites on (or near) national borders and having, to a certain degree, a unique permeable existence (Fleury, 2011; 2013). It is with such notions as place and space in connection with these reefs that help offer a distinct sense of uniqueness that adds to their inviting and fascinating existence as locations. Baldacchino observes that "shores are powerfully evocative places where elements, histories and ecosystems collide; the dynamic interfaces of the basic materialities of land, sea and air; interstitial spaces that can harbour high biological diversity; liminalities that are ever pregnant with possibility and surprise" (2012, p. 57). However, the Minquiers and Écréhous reveal an even more complex relationship to land and sea in that their spatial frame of reference waxes and wanes according to the movements of the moon.

At the edge of the Bailiwick of Jersey, and very close to the maritime border with France, the Minquiers and Écréhous can be conceived not only as part of a series of archipelagos (discussed later), but also within an aquapelago (Fleury, 2013; Hayward, 2012), which might be defined in this context as "an assemblage [generated by livelihood activities] of the marine and land spaces of a group of islands and their adjacent waters" (Hayward, 2012, p. 5). It is with such a notion that the reefs under study can be examined within a space that has been regularly contested, and a space that offers to a certain degree a shared location of land and sea. Moreover, as notes Baldacchino (2008, p. 220), "in spite of international borders attempting to be precise, they can at times prove fuzzy and somewhat ambiguous spaces".

Following this introduction, the main part of the article divides into two main sections. The first of these introduces the reefs under study from historical, geographical and political perspective. The next section examines contemporary issues and cross perspectives with a focus on fishing, environmentalism and tourism, each of which has major significance for the reefs in the present day. In this part of the article a discussion of these key themes that have emerged during the research process is offered as a way of contributing factual and theoretical ideas to the field of Island Studies.

\section{Border Islands, Reefs and Rocks}

The Minquiers and Écréhous reefs are located in different parts of the Gulf of St Malo (Golfe de Saint-Malo, or Golfe normand-breton) between the British island of Jersey and the French mainland (Figure 1). Administered as part of the Bailiwick of Jersey, and remaining Crown Estate, they are geographically very close to the international sea border that divides the territories of Jersey and France, and have had a history for several centuries of disputed sovereignty. Further, the reefs themselves help define the line boundary between the island of Jersey and the French mainland. They are currently uninhabited, but each has a small number of dwellings that are used by short-term visitors. In the present era, while the reefs are British Crown possessions, they also occupy a position in shared fishing waters between Jersey and France where fishing, environmentalism and tourism prevail. ${ }^{2}$

\footnotetext{
${ }^{2}$ There are other reefs off the island of Jersey, including Les Dirouilles and Les Pierres de Lecq (commonly called Paternosters), but these are smaller in comparison to the Minquiers and Écréhous and do not have
} 
Figure 1: Location map. (Designed by Christian Fleury.)

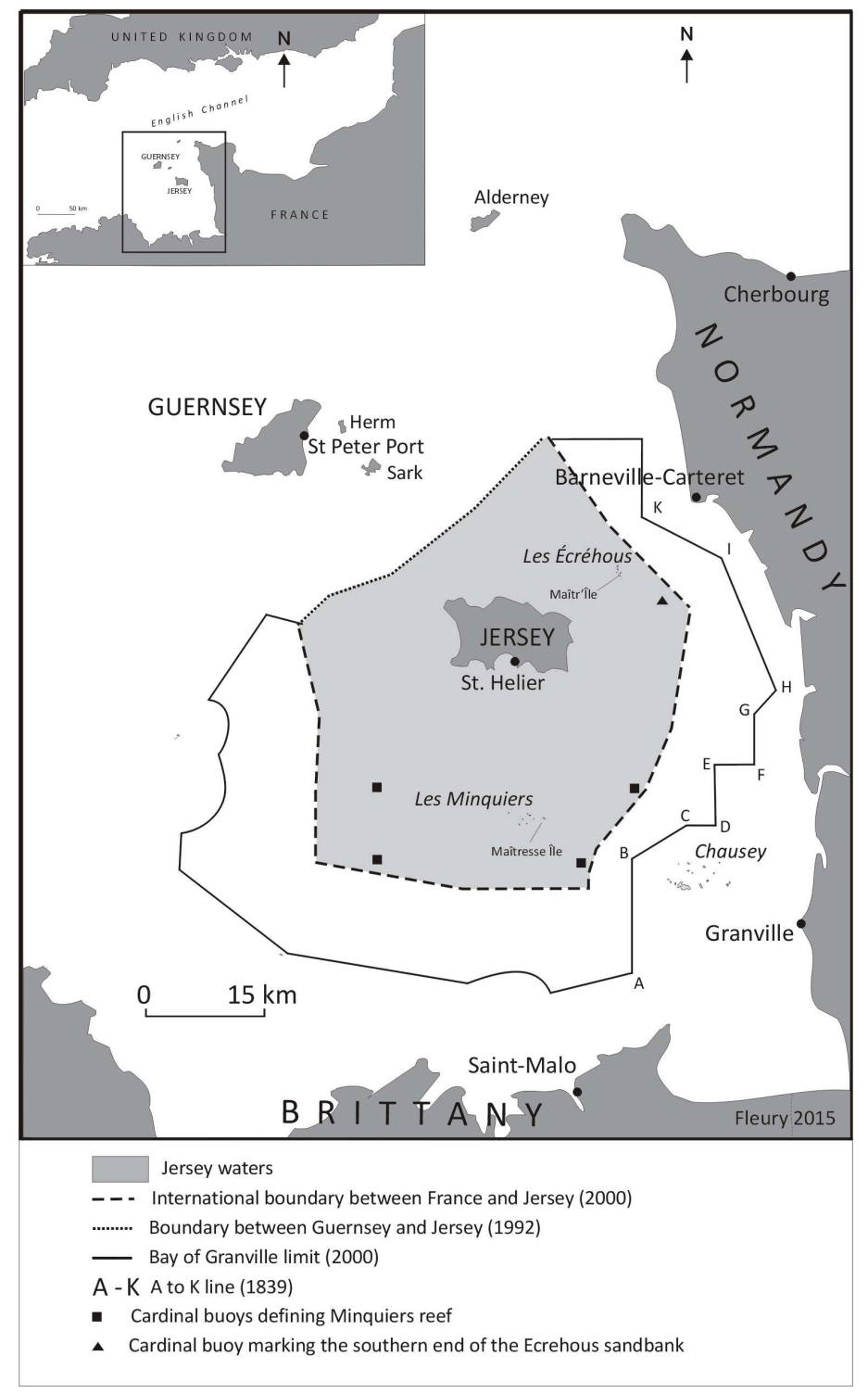

The reefs under study belong to a series of archipelagos. From a micro context to a relatively broader context, where the Minquiers and Écréhous show "borders within borders" (Baldacchino, 2010, pp. 22-41), they are a part of the Bailiwick of Jersey and the Channel Islands. This political division is expanded further to include the non-British islands nearby, such as Chausey. However, in the British setting, the Écréhous are the most eastern part of the Channel Islands, and the Minquiers are the most southerly part of the British Islands or the geographic British Isles more broadly.

Located about $20 \mathrm{~km}$ to the south of the island of Jersey and roughly the same distance away from the French archipelago of Chausey, the Minquiers are a rocky shelf in the shape of

dwellings on them. Several tidal islets and rocks around the island of Jersey have structures (e.g., historic forts) on them, which are not permanently occupied (Coysh, 1985). 
a rectangle about $16 \mathrm{~km}$ by $11 \mathrm{~km}$ and bounded by 4 cardinal buoys (Coom, 2001; Falle, 2001; Mallison, 2011; Sinsoilliez, 1995). The Minquiers are the most southerly part of the Bailiwick of Jersey, and are administered by the Parish of Grouville on the island of Jersey (one of 12 parishes). More specifically the reef is within the Vingtaine (division) of La Rocque and historically the fishers that usually worked the reef lived in that district of the parish (Falle, 2001, p. 91). ${ }^{3}$ The designation 'Minquiers' is conceptual in terms of referring to the body of reef material exposed above the continually changing tideline. Thus, the constant mass of the reef is somewhat ambiguous with regard to its nomenclature. It is, of course, not the mass and/or materiality of the geomorphological entity that varies, but, rather the mass that intrudes into the terrestrial world through its elevation above the sea and therefore its conceptualization and visibility (the two being highly connected). While only several very small islets and rocks are visible at high tide, this land and sea zone is close to $200 \mathrm{~km}^{2}$ at low tide (States of Jersey Planning and Environment Committee, 1999, p. 251). At high tide, and depending on the daily tidal coefficient, nine islets and rocks are visible, the largest of which is La Maitresse Île (see front cover of this journal), which is about $100 \mathrm{~m}$ long and $50 \mathrm{~m}$ wide (States of Jersey Planning and Environment Committee, 1999, p. 251). Several stone dwellings (known as "huts" [baraques]) are packed onto the islet, with several tiny pathways between some of them. The exact history of the huts on La Maitresse Île is not known, although in 1748 there were no dwellings on the islet (Godfray, 1929, p. 194). However, in 1792 men were based there to quarry the reef for granite to be used to build Fort Regent on Jersey, and by 1903 there were 18 mostly stone dwellings on the islet (Mallison, 2011, p. 73). A map of La Maittresse Île in 1929 showed 16 dwellings (Godfray, 1929, p. 192), and 12 exist today. Two of these are owned by the States of Jersey (remaining Crown land): one is administered by Port of Jersey (Jersey Harbours) and the other, the Impôts (customs) hut, is managed by the Parish of Grouville. In the 1970s a helicopter pad was built on the site of a former hut at the end of the islet well away from the main cluster of huts (Falle, 2001, p. 99).

The Écréhous, which are administered by the Parish of St Martin on the island of Jersey, have a linear shape as a series of rocks $11 \mathrm{~km}$ northeast of Jersey and $14 \mathrm{~km}$ off the Cotentin peninsula in Normandy (Rodwell, 1996; Rybot, 1933; Sinsoilliez, 1995) (Figure 2). The reef, the name of which is thought to mean "rocky islands" (Coysh, 1985, p. 103) in the Norman language, lies between France and Jersey in the sea route known as "Le Passage de la Déroute". There is a single cardinal buoy at the Écréhous, which marks the southern end of the nearby L'Ecreviere sandbank. As an archipelago/aquapelago of islets, rocks, shingle, sandbanks and sea, like the Minquiers the actual area occupied by the Écréhous is dependent on the tide level, thus the land and sea zone ranges from about 0.2 to $41 \mathrm{~km}^{2}$, with the central plateau, which itself consists of several islets and rocks at high tide, being about $4 \mathrm{~km}^{2}$ at low tide (States of Jersey Planning and Environment Committee, 1999, p. 243). As with the Minquiers, there are several "huts" packed tightly onto one of the islets (La Marmotière), with several dwellings on a few other islets and rocks that are joined at low tide by a shingle bank (La Taille). The main islets in the Écréhous are named Maîtr'̂̂le (the largest at high tide), La Marmotière, ${ }^{4}$ Le Blanqu' ̂̂le, La Grande Brèche and La Petit Brèche, with smaller rocks including Rocheport, Bouvet, Sabloniere, Bigorne and Grosse Tete (each with various spellings) (States of Jersey Planning and Environment Committee, 1999, p. 243). There are two huts on Maîtr' $̂$ le, one each on La Grande Brèche and La Petit Brèche, and four properties

\footnotetext{
${ }^{3}$ Private property on the Minquiers is rated as part of La Rocque (Falle, 2001, p. 96).

${ }^{4}$ La Marmotière is featured on the reverse side of the Jersey 50 pound note.
} 
on Le Blanqu' $̂ l e$, which itself divides into two main rocks divided by a shingle causeway. La Marmotière has 21 numbered dwellings, several of which are huts that have been divided into two parts. No. 9 is particularly interesting for Island Studies in that it sits on its own rock, known as "The Island" that has just a narrow shingle path between it and La Marmotière. ${ }^{5}$

\section{Figure 2: Écréhous at low tide. Right of photo: La Marmotière; left of photo: several smaller islets. (Photo by Henry Johnson, 2014.)}

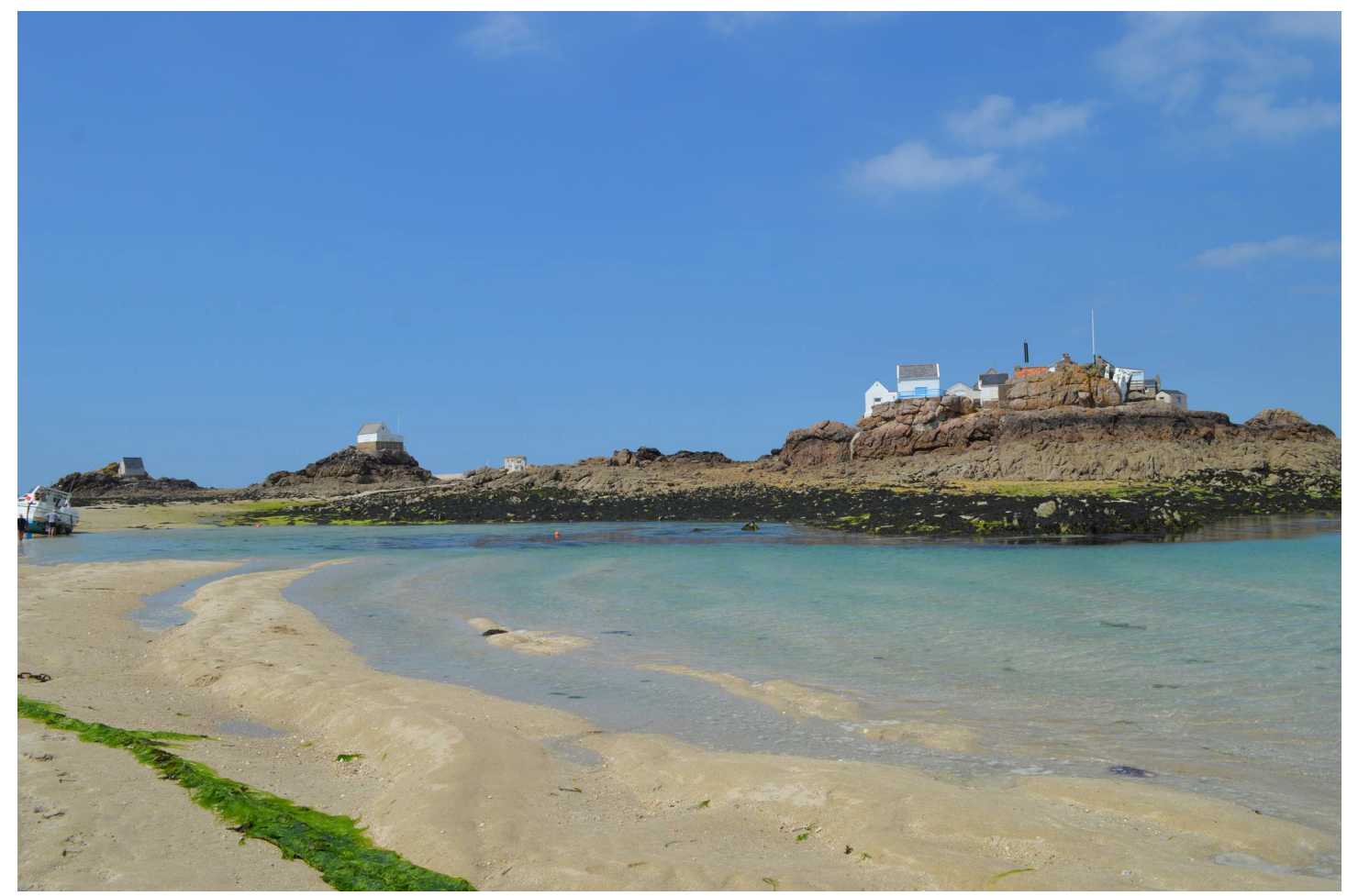

Along with the main Channel Islands (e.g., Jersey, Guernsey, Alderney, Sark and Herm), these two shelves are situated in different parts of the pronounced Gulf of St Malo in the northern French coastline (between Normandy and Brittany). This area is characterized by challenging marine conditions due to the combination of two overriding major factors: the presence of countless rocks and sand, and the strength and range of tidal currents, which are among the highest in the world (up to 12 metres). These two factors combine to make the tidal waters around the Minquiers and Écréhous to be especially dangerous, yet also creating a very changeable amphibious and distinct seascape/landscape. As one hut owner on the Minquiers noted in response to a short survey: "The Minquiers plateau is an area of unique, constantly and dynamically changing beauty. It is a place to enjoy vast skies, and multi-toned sea, rocks and sand" (Anon, 2015, personal communication). With both reefs, and especially with the Minquiers, only a few rocks remain above the high-water mark, whereas at low tide a huge plateau is uncovered, along with a number of rocks, sandbars and sea inbetween. Added to the fact that the situation is never the same depending on the time of day due to the tidal

\footnotetext{
${ }^{5}$ Rodwell (1986) includes a study of the archaeology of huts on Maîtr' ̂̂le.
} 
conditions, it is not surprising that only experienced navigators are able to visit safely these areas. As one adventure tourism operator to the reefs has noted,

Visiting the islands is always special. . . . The scenery is constantly changing out there with the tides and is always special. I love Les Ecrehous in all weather, and the Minquiers is incredible on a low tide, it is a huge expanse of rock and sand and I feel I have only explore[d] about $10 \%$ of the reef! (Anon, 2015, personal communication)

As a spatial paradox that combines physical closeness yet at the same time being particularly difficult locations to access, the Minquiers and Écréhous appear as intriguing sites and have traditionally been visited by only a small numbers of people. While geographically remote, they are, however, not necessarily in the middle of nowhere, but, rather, at the heart of a densely populated area comprising the Channel Islands, the Brittany and Normandy coasts, and a number of French islands, islets and rocks, which adds to their geographical, historical and political importance near the border of different jurisdictions. In connection with the location of the reefs, one informant noted a distinct difference in terms of the type of visitors based on the maritime skills required to get there,

Les Minquiers are more remote and exposed. In my mind I see them as being a sort of wild west territory which is still largely uncharted and unexplored. Getting in and out of the reef is tricky and when there it is remote with few facilities and not many visitors. Every visit to Les Minquiers is to be savoured; there is something raw and primeval about the reef and yet on a clear, still day it takes the form of a tropical paradise. There is a camaraderie amongst Minquiers visitors that one does not get at Les Écréhous. This is probably because you need to be reasonably competent to get a boat there and so the reef does not attract quite so many party goers (although it does have them). I don't think I've ever had any tricky conversations about sovereignty with French visitors at Les Minquiers whereas I have had plenty at Les Écréhous. (Anon, 2015, personal communication)

These areas have been turbulent regarding navigation and neighbourly (political) relations. During the troubled times in the areas in the early $13^{\text {th }}$ century, the Channel Islands had not been concerned when Normandy was integrated into the French Kingdom in $1204,{ }^{6}$ and it could be said that the Minquiers and Écréhous had been considered "neutral" areas. The question of sovereignty over the reefs wasn't really on the political agenda at the time, and the areas were solely dedicated to fisheries by workers visiting from both France and Jersey (Sinsoilliez, 1995, p. 97). This is especially true from a French point of view and from a contemporary perspective. Jersey fishers, mostly coming from La Roque in the southeast of Jersey for the Minquiers, and from the northeastern parish of St Martin for the Écréhous, gradually built wooden then stone "huts" on the inhospitable main islands. While French fishers have made much use of the very abundant resources of fish and crustaceans in these locations (e.g., conger, lobsters, brown crabs and spider crabs), they never planned to build on the islands. From the French side, as well as an incursion in 1888, several attempts to build on Maitresse Île in the Minquiers came from outside of the fishing industry, including those of

\footnotetext{
${ }^{6}$ For a comprehensive analysis of the different reasons of the division of Normandy between mainland and islands, see Everard and Holt (2004).
} 


\section{Fleury \& H. Johnson}

the Parisian financier Édouard Le Roux in 1929, and a decade later with the painter and sailor Marin Marie (Sinsoilliez, 1995, pp. 150, 181). In 1984, the famous novelist Jean Raspail, wellknown in France for his nationalist sentiment, landed on the Minquiers. He then hoisted the Patagonian flag beside the British flag in an ironic way to denounce the British occupation of the Falkland Islands. ${ }^{7}$ Later, in 1998, the British flag on the Maitresse Île was removed and handed to the British ambassador in Paris by Raspail. This later event was even reported in several articles in the British press, including the Daily Telegraph (2 and 5 September 1998) and Daily Mail (2 September 1998). With regards to the Écréhous,

In 1993 and again in 1994, French 'invaders' from mainland Normandy landed on Les Écréhous and raised Norman flags. This was done partly in protest against Channel Island fishing regulations and partly because they wanted Les Écréhous to be recognised as part of France. The 1994 'invasion' was monitored closely by police from Jersey, and the Union Flag that had been pulled down in 1993 was guarded by policemen. In the end, after only minor trouble being caused, the French had lunch on the islands before going back home. (States of Jersey, 2012a, p. 11)

Even though such incursions raise questions about the sovereignty of the reefs, and offer a sense of invasion, each of these cases was settled peacefully and diplomatically.

Because St Malo and Granville had been two of the most important French ports for cod fisheries at the Newfoundland banks, the French have noted that the Minquiers are a serious navigational hazard for access to these ports. After a series of shipwrecks that occurred around the middle of the $19^{\text {th }}$ century, the French placed a beacon on the main islet and several white marks on some rocks (Fergusson, 1888). For example, the ship, La Marie, was wrecked off the Minquiers on 30 November 1861 with the loss of 51 people after coming from SaintPierre-et-Miquelon to Granville at the end of a cod fishing season, which led four years later to the installation by the French administration of an unmanned lightship southwest of the reef (Sinsoilliez, 1995, p. 134).

The tense relations amongst fishers from both sides of the reefs, as well as the pressure of the local authorities - mostly coming from Jersey rather than France - along with changes in international law, led eventually in the 1950s to an appeal for international arbitration. On its part, the United Kingdom mainly tried to reduce the Jersey passion around the question, especially in the context of a warming relationship with France throughout the $19^{\text {th }}$ century and thereafter. The dispute over the reefs was addressed on different levels, from the often tense relations on the ground to the informal discussions being held by diplomats. However, the latter didn't prevent a number of gesticulations, among them the most significant being the visit in April 1938 of the French Prime Minister Édouard Daladier to Maîtresse Île in the Minquiers. This event occurred a few months before the escalating tension with Germany, which put the dispute over the reefs on hold until the end of the Second World War (occupying German troops in the Channel Islands were stationed on the Minquiers as part of an observation post). It was only just before the war that French fishers started to be seen in large numbers working on and around the reef, and as a result of Jersey fishers being prohibited from visiting there during the occupation of the Channel Islands, the last year of the

\footnotetext{
${ }^{7}$ Jean Raspail published in 1981 Moi Antoine de Tounens, roi de Patagonie, the real story of an eccentric French lawyer who proclaimed himself King of Araucania and Patagonia in November 1860. He was dismissed by the Chilean authorities in January 1862 and then repatriated to France.
} 
war saw many French fishers there because they had been liberated much earlier than the Channel Islands (Falle, 2001, p. 97). Jersey authorities have made frequent visits to the reefs as a way of exercising jurisdiction over them, but, due to continuing disputes over sovereignty of the two reefs, in the post-War years, arbitration was sought in the International Court of Justice, which had recently been established for solving international territorial disputes. The case was held in The Hague in 1953, and both countries put forward their respective and different interpretations of the reefs, which were based on land occupancy by building huts from the Jersey perspective, and on numerous fishing activities from the French perspective. It became apparent to the observers that the British argument was far more documented because of the existence of the huts on the reefs, and, although received with bitterness by the French, it was not a surprise that the decision in 1953 gave the Minquiers and Écréhous to the Bailiwick of Jersey: "that the sovereignty over the islets and rocks of the Ecrehos [Écréhous] and Minquiers groups, in so far as these islets and rocks are capable of appropriation, belongs to the United Kingdom" (International Court of Justice, 1953, p. 72). Such are the official visits to the reefs by Jersey authorities that they have often included the Bailiff and/or Lieutenant Governor (Crown appointments), and are now the responsibility of the Minister and Assistant Ministers of the Economic Development Department.

\section{Contemporary issues and cross perspectives}

\section{Fishing}

The rights to areas for fishing have often been a topic of dispute between Jersey and France. The presence of the Channel Islands as British enclaves in the Gulf of St Malo led inevitably to conflict and resolution over the use of the sea. Several international agreements or conventions between France and the UK have been made, the first of which related to the fishing of oysters and was signed on 2 August 1839, with others made at various times over the years, including 1843, 1928, 1851, 1951, 1964, and 1965 (see Agreement, 2000b, p. 11). The first of these was a convention and represented an early example of a cross-border sharing for fisheries and introduced two exclusive areas relating to land and sea: (1) A three nautical mile zone of water around Jersey that excluded French fishers; and (2) A border line referred to as "A to K" (indicated by the letters A, B, C, D, E, F, G, H, I, K), ${ }^{8}$ the French side of which was closed to Jersey fishers (Convention, 1839, in Hertslet, 1840, pp. 87-88). As a result of bad weather or damage, British fishers were given the right to shelter on the French islands of Chausey, southeast of the Minquiers (Convention, 1839, in Hertslet, 1840, pp. 88). But on the Jersey side of the points, and outside Jersey's exclusive zone, the two jurisdictions help form a common sea inbetween that relates to the old principle of res communis (belonging to everyone) as mentioned in the Justinian Code of the $6^{\text {th }}$ century and taken up at the beginning of the $17^{\text {th }}$ century by the Dutch jurist Hugo Grotius (Fleury, 2011, p. 27). However, the Minquiers and Écréhous were not specifically mentioned in the 1839 Convention, presumably because at the time they shared a common area of sea and land that was open to both countries.

As noted earlier, the pressure by Jersey on the UK government to solve the dispute over the reefs resulted in a confrontation at the International Court of Justice. However, the decision of 1953 did not jeopardize the fishing rights of French fishers in the reefs because of an agreement signed in 1951, which specified, prior to the case, that fishers would be able to

\footnotetext{
${ }^{8}$ The letter "J" is omitted, following an early custom when using letters in lists.
} 


\section{Fleury \& H. Johnson}

continue to fish in select areas within the waters of each territory. Such an agreement offered a distinct sharing of the reefs for traditional fishing rights, yet the reefs are now internationally recognized as falling within the Bailiwick of Jersey. This provision applies above all to the rich resources in crustaceans that are found in the Minquiers and Écréhous.

By the mid-twentieth century, the convention of 1839 was no longer enough to prevent the intrusion of external fleets. As the risk increased, the need to prevent possible intrusion became increasingly critical. At the same time, the developments in international law made the establishment of marine borders for islands such as Jersey inevitable. Therefore, after the 1953 court case the French resolved to negotiate what they wanted to be considered only as a slight variation of the 1839 convention. The task was not easy because the talks between France and the UK led only to an agreement in 2000 after 13 years of discussing the minutiae of the Minquiers and Écréhous and their surrounding waters. One Jersey politician described the task as counting "rock by rock" on a "long and winding road" (Fleury, 2006, p. 414). Once again, and behind the scenes, French fishers put pressure on the French authorities to make sure the agreement on territorial delimitation would not jeopardize their access to waters that had now become foreign waters through the clauses of the new agreement. These negotiations were concluded with the signature in St Helier on 4 July 2000 of two international agreements: the first concerned the definition of an international marine boundary between France and the Bailiwick of Jersey; and the second the blurring of this line specifically for fishing matters. The latter agreement restricted some French access in the old common sea as defined in the 1839 convention (in the three mile strip around Jersey), but left the situation unchanged in the Minquiers and Écréhous. Such an agreement aligned with the idea of traditional fishing rights as mentioned in Article 51 of the United Nations Convention on the Law of the Sea, which states that "an archipelagic State shall respect existing agreements with other States and shall recognize traditional fishing rights and other legitimate activities of the immediately adjacent neighbouring States in certain areas falling within archipelagic waters" (United Nations, 1982, p. 32).

The fisheries agreement of 2000 can be seen as a renewed granting of French access to the reefs. The strength of an international agreement such as this one can be illustrated through the recent attempt in 2014 by the Jersey Harbour authorities to ban for safety reasons fishing activities in the immediate vicinity of the two largest islets in the Minquiers and Écréhous. This proposal was put forward in the context of the partial privatization of the Harbour facilities by the government of Jersey. That threat turned into a mere recommendation due to the reassertion of the intangible character of the provisions of the agreement by the fishers from both sides who work together within a common management body, the Joint Advisory Committee of the Bay of Granville.

Thus, the Minquiers and Écréhous have benefited from a combination of favorable factors for the limitation of fishing activities. The first ones are de jure since they come from either the agreement provisions or specific regulations for some parties. With regard to crustacean fisheries, technical measures have been put into place such as the minimum catch size and the number of pots. ${ }^{10}$ Further, access to the reefs is restricted to local fishers (i.e., those from Jersey and France). As well as the severe nautical constraints, there are limiting factors, which are de facto as only a handful of fishers work there all year round. During

\footnotetext{
${ }^{9}$ Christian Fleury is an observer of the three-yearly meetings of the Joint Advisory Committee of the Bay of Granville.

${ }^{10}$ Only from the French side (200 pots). Jersey has still not implemented such measures.
} 
research, fishers answering questions about such numbers reported a presence of about 5 to 8 potters (fishers who catch lobsters and crabs) in total from France and Jersey in the Minquiers and the Écréhous generally fishing alone on small boats. While potters are the only fishers who are able to work everywhere in the reefs due to the dangerous nautical conditions, discussions are currently under way to limit the activities of dredge fishing both in the Minquiers and the Écréhous. This relates to dredgers and trawlers that periodically work on the periphery of the reefs.

With regard to fisheries, for Jersey and France the convention of 1839 , along its revision in 2000, provided a means for the Minquiers and the Écréhous to be shared within a framework that acknowledged these zones according to historical fishing rights. While the Minquiers and the Écréhous were not specifically mentioned in the original agreement, by the twenty-first century their importance for both Jersey and France became apparent in connection with fisheries. It is with this industry that the Minquiers and the Écréhous occupy inbetween spaces, and as land and sea zones that have been given flexible boundaries. The notion of liminality helps explain that these reefs offer a sense of being "islands inbetween", where cross-border sharing has been established for fisheries close to the political edge of two jurisdictions. Fishers may work in the Minquiers and the Écréhous, and while these reefs are now a legal entity within the Bailiwick of Jersey, they offer a space with a unique permeable existence. The idea of the Minquiers and the Écréhous as liminal locations is based on the convergence of their geographic position near the edge of the Bailiwick of Jersey, being close to the international marine border between Jersey and France, and existing within an agreement that allows a degree of sharing of land (i.e,. visiting the reefs), sea (i.e., moving within them) and fisheries resources (i.e., traditional fishing rights).

\section{Environmentalism}

In recent years, the Minquiers and Écréhous have become the focus of environmental activism. Both reefs became Ramsar wetlands sites of international importance in 2005 (States of Jersey, 2011a; 2012a; b). ${ }^{11}$ Because of their relative isolation in dangerous waters between Jersey and France, they have not only a distinct landscape and seascape, but also flora and fauna. As one co-owner of a hut has noted in connection with the Minquiers, "the sheer size of the reef at low water and how little there is left at high tide, and witnessing this great movement of water taking place twice a day is really quite breathtaking" (in Mallison, 2011, p. 91). The reefs are particularly well known for their bird and marine life. Indeed, the marine life has for many years, as discussed above, been a valuable resource for fisheries, and more recently abundant seal and dolphin colonies have been especially inviting as tourist attractions in the developing marine adventure tourism industry in both Jersey and France. While discussing the possible threats to the Minquiers within Jersey's Ramsar plan, Jersey authorities have noted that "the site is frequented by both Jersey and French nationals who fish throughout the reef, on both a commercial and recreational basis" (States of Jersey, 2012b, p. 12). Further, the recreational impact on the Minquiers is noted in Jersey's Ramsar plan, which points out that while it is

\footnotetext{
11 The Ramsar Convention was adopted by the United Nations in 1971 to provide an intergovernmental framework for the conservation of wetlands (Ramsar, 2015). Six sites in the Channel Islands are listed (Secretariat of the Convention on Wetlands, 2014, p. 45). One for Alderney (covering the west coast, adjacent waters and the Burhou islands); four for Jersey (the area of Les Écréhous and Les Dirouilles reefs; Les Minquiers reef; Les Pierres de Lecq reef; and the southeast coastal area of Jersey); and one for Guernsey (embracing the L'Erée headland, Lihou Island and the surrounding waters).
} 


\section{Fleury \& H. Johnson}

limited it can have a serious effect during the breeding season with such factors as speeding vessels, jet skis, and "up to 20 vessels . . . reported on some days at the main anchorage" (States of Jersey, 2012b, p. 13). A similar situation but with many more vessels and visitors has been reported on the Écréhous where "the sheer volume of general visitors to the reefs can be a potential threat if appropriate management steps are not taken. Up to 80 vessels have been reported on some days with several hundred people on land" (States of Jersey, 2012a, p.14). In this context, as one hut owner on the Minquiers noted, "the environment needs to be preserved for future generations" (Anon, 2015, personal communication).

The significance of the Minquiers and Écréhous as environmental sites is acknowledged in the ongoing discussions about the possible utilization of wind and tidal power around Jersey. Equipment used to monitor the wind within Jersey's waters has been set up on rocks $3 \mathrm{~km}$ and $6 \mathrm{~km}$ from the main islands in the Écréhous and Minquiers respectively (States of Jersey, 2015). One of the possible sites runs through the Écréhous, with the other between the Minquiers and Jersey. The appearance of the former in one report raised concerns from environmental protection groups such as The National Trust, Save Our Shoreline, 'Les Ecrehous' Residents Association, and the Marine Section of Société Jersiaise (States of Jersey, 2011b, p. 13). Indeed, 'Les Ecrehous' Residents Association was formed in 2009 as a result of the rapid increase in the number of visitors to the reef over the previous decade. Its aims are,

1. to maintain and preserve the peaceful atmosphere, beauty and tranquility of the Ecrehous;

2. to preserve the natural environment and wildlife of the Ecrehous for all;

3. to ensure the sustainable use of the Ecrehous as a safe and valued environment for the enjoyment of all those who visit the Ecrehous; and

4. to express an opinion or make representations on matters relating to the Ecrehous ('Les Ecrehous' Residents Association, 2015).

In this context, however, the States of Jersey has commented that "any developments of renewable energy should not compromise the quality of life of Jersey's people or its biodiversity" (States of Jersey, 2011b, p. 4). Further, any possibly developments for alternative energy sources in these sites would have to be considered in the context of The Granville Bay Agreement of 2000 as discussed above.

As well as their environmental importance, the reefs are also of cultural importance. Neolithic pottery has been found in the peat beds on the Écréhous (States of Jersey Planning and Environment Committee, 1999, p. 236), and the Minquiers were a site of occupation in the Bronze and Iron Ages (States of Jersey Planning and Environment Committee, 1999, p. 236). Indeed, the Écréhous have been described as being "one of the richest archaeological sites in Jersey" (States of Jersey Planning and Environment Committee, 1999, p. 244). In the thirteenth century the Écréhous had a Cistercian Priory (States of Jersey Planning and Environment Committee, 1999, p. 237). However, not long after, "both reefs were uninhabited by the fifteenth century and in the early modern period they are portrayed from surviving records as dangerous places, on the edge of the law, with passing visitors using the natural resources of vraic [seaweed], fish and stone that the islands had to offer" (States of Jersey Planning and Environment Committee, 1999, p. 237). By the early nineteenth century, and after centuries of conflict with France, "from around 1830 onwards the way in which the reefs were used by Jersey people began to change. Peace with France in 1815 made the reefs more 
accessible and secure and growing numbers of people began to reside on the islands permanently, invest in grander properties and exploit the leisure potential of the islands" (States of Jersey Planning and Environment Committee, 1999, p. 237). Nevertheless, tensions between Britain and France again rose in the late nineteenth century, and the British claims to sovereignty were consolidated with flagstaffs on each reef (States of Jersey Planning and Environment Committee, 1999, p. 237). It was not until the 1950s, however, as noted earlier, that French and British claims to the reefs took to formal levels of mediation in the International Court of Justice. Even so, as Coysh (1985, p. 106) comments, "curiously, both the British and French flags are to be seen there at times, but flying from separate poles!".

The Minquiers and Écréhous are sites of historical importance for the history of the broader region. While the reefs are located on the edge of the Bailiwick of Jersey and near the maritime national border between Jersey and France, their peripheral existence is sometimes given prominence over their cultural and national significance. If the notion of liminality is to be applied to culture and the environment, it would help show that cultural heritage at the Minquiers and Écréhous exists in an inbetween space that is obfuscated by the archipelagic and aquapelagic context in which the reefs now exist. Further, because of their relative isolation and absence of a permanent population, ${ }^{12}$ the reefs have been allowed to become Ramsar wetland sites. It is partly due to their location on the edge of the Bailiwick of Jersey and well away from a populated area that have helped the reefs be designated at protected sites. A visit to these wetland sites offers tourists an experience of travelling to a nearby yet at the same time distant "other", whether from Jersey or from France, where the journey across the sea offers a sense of moving into the liminal space that the Minquiers and Écréhous have to offer visitors during the (usual) short-term stay on the reefs.

But tensions arise when such environmental protection is considered in light of increased demands for alternative energy sources such as wind and tidal power, each of which has been considered in areas around the reefs, as well as increased tourism. Also, with increased visits to the reefs by tourists on private yachts or as part of a growing adventure tourism industry (discussed next), tension between those who want to protect and those who want to develop might arise.

\section{Tourism}

While the early years of visits to the Minquiers and Écréhous from Jersey was primarily for fishing or quarrying (States of Jersey Planning and Environment Committee, 1999, p. 237), most other visitors have been yachtsmen and kayakers. Such visitors would usually travel on a non-commercial basis. However, travel to these locations in this way helped reinforce the reefs as locations on the edge of the Bailiwick of Jersey and between Jersey and France, and places that offered an escape for those able to make the journey. As a result of an increased demand for sport and adventure tourism, more recently the reefs have been opened up to more visitors as a result of tour operators offering excursions (usually for part of a day, a full day or occasionally overnight), either for canoeists or for visitors aboard yachts or high-speed RIBs (rigid hulled inflatable boats).

\footnotetext{
${ }^{12}$ The only long-term resident on the reefs in recent years was Alphonse Le Gastelois (1914-2012) who lived on the Écréhous in self-imposed exile for 14 years until 1975. As with the fisherman Philippe Pinel (1820-96), who lived on Le Blanqu' ̂̂le in the Écréhous from 1848 until around 1895, Le Gastelois was locally known as the "King of the Écréhous" ("Le Roi des Écréhous").
} 


\section{Fleury \& H. Johnson}

Jersey Kayak Adventures is a Jersey company that was established in $2003 .{ }^{13}$ Its guided trips include a range of options such as visiting the Minquiers, Écréhous, Sark, Seymour Tower (an eighteenth-century military tower built on a rock called L'Avarison about $2 \mathrm{~km}$ off the southeast coast of Jersey) and Chausey, which is almost midway between the Minquiers and Granville. While operating all year, the local climate favours visitors during the summer months. Excursions to the Minquiers and Écréhous are either trips by kayak from Jersey, or around the reefs after traveling there by charter boat from Jersey. Small groups of up to 10 kayakers enjoy not only the short trip to the reefs, but also the possibility of seeing dolphins and other sea and birdlife, and kayaking around the various islets, rocks and sand bars.

The Minquiers and Écréhous have been further consolidated into the Bailiwick of Jersey as a result of adventure sea tourism. In particular, two businesses have established adventure trips to the reefs and other locations on high-speed craft (i.e., RIBs). Island RIB Voyages was established in 2006, and Jersey Seafaris in $2011 .{ }^{14}$ In connection with Seafaris, for example, while operating a single craft until the end of 2014, early in 2015 the company purchased a second RIB, which is slightly longer and with more powerful engines than the first craft. The boats belonging to both businesses can take up to 12 passengers. As well as these two reefs, the operators also take sightseers to other off-shore locations, including north coast tours of Jersey, the Chausey islands, mainland France, as well as private charters. Each of these is part of a type of tourism venture offering same-day excursions. The trips make much of the extremes of local tides, the often hidden parts of the nearby reefs, sandbanks (Figure 3) and marine life such as dolphins, seals and birdlife that are found in these locations.

Since these businesses were established, they have allowed large numbers of locals and visiting tourists alike to experience these offshore reefs. Operating mainly from March to October, they offer trips of two to three hours to the Minquiers and Écréhous on a regular basis, taking just 10-15 minutes to reach them, usually alternating the locations on consecutive days and sometimes making two trips to the same location in a single day (see also Allo, 2014). They have opened up both reefs significantly to visitors and residents of Jersey. While both groups would travel with such tour operators as part of a touristic experience as either a local or visitor to Jersey, the number of such visitors who have been able to experience the reefs over the past decade has not only increased many times over, but perhaps most importantly for this article such visitors help show the importance of offshore reefs as sites that have much importance in the field of Island Studies.

A further tour operator is Wetwheels Jersey, which has been operating since $2013 .{ }^{15}$ This charitable organization provides marine experiences for disabled and disadvantaged Jersey people, and there is no cost for the passengers. Its excursions on its 9.2-metre catamaran have included visits to Guernsey, Sark and the Minquiers.

While the reefs are now both Ramsar wetlands sites, this very protection adds to their attractiveness as sites to visit. Indeed, such "increased visitor pressures are a threat" (States of Jersey Planning and Environment Committee, 1999, p. 240) not only to archaeological remains, marine and birdlife, but also to the sense of the reefs as an important part of the distant seascape when viewed from the island of Jersey. With regard to the Écréhous, for example,

\footnotetext{
${ }^{13}$ See http://www.jerseykayakadventures.co.uk/ (accessed 7 April 2015).

${ }^{14}$ See http://www.jerseyribtrips.com/; http://www.jerseyseafaris.com/ (accessed 7 April 2015).

${ }^{15}$ See http://www.wetwheels.je/ (accessed 15 May 2015).
} 
The main threat relates to the increasing human disturbance to the fragile environment of Les Écréhous. They are easier to reach than the Minquiers and lie just 8 miles from Carteret, a significant fishing port and site of a new 300 berth marina. Recent years have seen a great increase in tourist visits from both Jersey and the French mainland and this is likely to continue. (States of Jersey Planning and Environment Committee, 1999, p. 240).

Figure 3: Sandbank at the Minquiers. (Photo by Henry Johnson, 2014.)

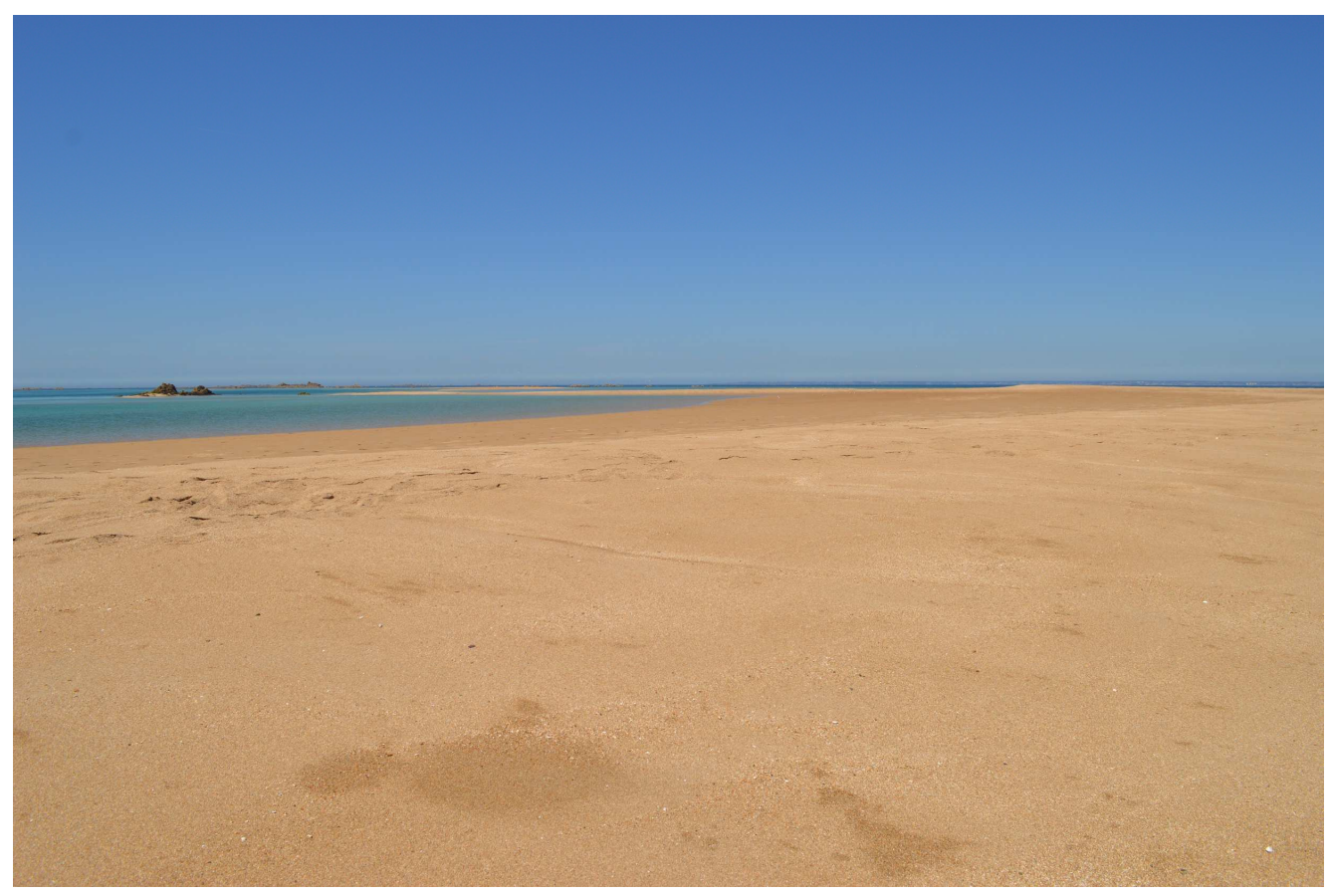

Moreover, "the uninhabited reefs and rocks are an important part of the horizon view from the more developed coast of Jersey" (States of Jersey Planning and Environment Committee, 1999, 240), and "the special sense of remoteness and wideness is being eroded by increasing human disturbance" (States of Jersey Planning and Environment Committee, 1999, p. 240). From the French side, the uniqueness of the Minquiers and Écréhous reefs is distinctly singled out in some promotional brochures of a handful of sea excursion companies operating from the port of Granville. As an example, one of these companies, Le Courrier des Iles, describes the Minquiers in a representative manner as follows: "A huge chaos of reefs and sandbanks crossed by violent streams. Inviolate territory of countless seabirds. Vision of another world, you are at the heart of the most powerful tides in Europe. Very few people before you have had the privilege of experiencing this unique landscape" (Le Courrier des Iles, 2015, authors' translation). Adding to a sense of adventure tourism, this company operates several motor yachts and a high-speed RIB to the Minquiers.

While the Minquiers and Écréhous have distinct navigational hazards due to the countless rocks, currents and the ever moving tides, their natural context offers challenges for tour operators such as those outlined above, but these challenges add to the growing interest in adventure tourism. As liminal locations as defined by a combination of their location, natural 


\section{Fleury \& H. Johnson}

environment and overlapping context as defined for some fisheries as a result of The Granville Bay Agreement of 2000, the reefs have much to offer in the excursion tourist industry, especially within adventure tourism where travel by sea on a RIB, kayak or yacht allows the visitor to pass from land (Jersey or France) over sea to reach the reefs. It is this travel across the sea that offers tourists a sense of moving to an inbetween space.

\section{Conclusion}

The Minquiers and Écréhous exist in a space of sea and islands that is contested in several ways. Historical tensions between England and France were played out on the reefs over the many centuries since King John lost his Norman lands (except for the Channel Islands), and as Jersey increasingly exercised jurisdiction over the reefs, such political manoeuvring raised tensions between the two closely connected territories.

Historical and contemporary politics has played a large part in defining these reefs, and much of this has been about not only land (partly because there is very little at high tide), but more about the sea in which the reefs are located. The interconnectedness in terms of interjurisdictional relations, historical fishing rights, environmentalism and tourism are foregrounded in many ways in the sea within and around the Minquiers and Écréhous. In some ways it is the sea itself that defines the land: a particularly wide tidal flow making the reefs tiny at high tide, yet vast at low tide; providing rich resources for the fishing industry; providing environmentalists a land and sea context that offers many distinct features, both physical and natural; and a setting where adventure tourism must negotiate the opening up of the reefs to more visitors, yet at the same time comply with the need to protect their distinct environment that makes the reefs attractive to visitors in the first place.

As border islands, the Minquiers and Écréhous are locations inbetween: Jersey and France, land and sea, protection and development, and past and future. Visiting the reefs offers a sense of travel, and reaching a location on the edge of one jurisdiction and in close proximity to another. In this spatial context of land and sea, and ebbs and flows, therefore, the Minquiers and Écréhous engender liminality where politics, historical fishing rights and leisure activities collide in a space that is defined by sea and land, tidal flows and changing landscapes. To conclude, we must return to the decision by the International Court of Justice in The Hague in 1953, which favoured Jersey's historical land occupancy and jurisdictional history. However, at that time it was the land of the reefs that was given special importance, whereas nowadays it is the aquapelagic context, which includes fisheries, environmentalism and sea tourism that is increasingly the dominant element that actually defines the importance of the reefs.

\section{Acknowledgements}

The authors would like to thank Philip Hayward for his insightful comments on an earlier draft of this article. Thanks also go to the anonymous respondents of a short survey on the Minquiers and Écréhous, Greg Morel for information on the cardinal buoy at the Écréhous, Paul Chambers for sharing much knowledge on the reefs, and the anonymous referees for the suggestions that have been incorporated into the text. 


\section{References}

Agreement between the United Kingdom of Great Britain and Northern Ireland and the French Republic concerning the establishment of a maritime boundary between France and Jersey. St Helier, 4 July 2000a.

Agreement between the Government of the United Kingdom of Great Britain and Northern Ireland and the Government of the French Republic concerning Fishing in the Bay of Granville, with Exchanges of Notes and Declaration. St. Helier, 4 July $2000 \mathrm{~b}$.

Allo, L. (2014). A trip to the Écréhous with Jersey Seafaris. Les Nouvelles de St Martin, 9, 24-25.

Ankei, Y. (2013). The fieldwork ethics and positionality of Tsuneichi Miyamoto: a pioneer of border island studies in Japan. Eurasia Border Review, 4(1), 19-42.

Baldacchino, G. (2008). Islands in between: Martín García and other geopolitical flashpoints. Island Studies Journal, 3(2), 211-224.

Baldacchino, G. (2010). Island enclaves: Offshoring strategies, creative governance and subnational island jurisdictions, Montreal, Canada: McGill-Queen's University Press.

Baldacchino, G. (2012). The lure of the island: a spatial analysis of power relations. Journal of Marine and Island Cultures, 1(1), 55-62.

Bhabha, H. (1994). The location of culture. New York: Routledge.

Convention between Her Britannic Majesty and the King of the French, defining and regulating the limits of the exclusive right of the oyster and other fishery on the coasts of Great Britain and of France. Paris, 2 August 1839. In Hertslet (1840, pp. 86-94).

Coom, D. (2001). Livings from the reef. In R. Anthony (Ed.), Grouville, Jersey: The history of a country parish (pp. 100-105). Grouville, Jersey: Parish of Grouville.

Coysh, V. (1985). Channel islets: The lesser Channel Islands. Vale: The Guernsey Press.

Everard, J., \& Holt, J. (2004). Jersey 1204: The forging of an island community. London: Thames \& Hudson.

Falle, R. (2001). Les Minquiers. In R. Anthony (Ed.), Grouville, Jersey: The history of a country parish (pp. 91-99). Grouville, Jersey: Parish of Grouville.

Fergusson, J. (1888, June 4). Parliamentary debate: Channel Islands: Min-Quier Islets. Hansard, 326, c1024. Retrieved from http://hansard.millbanksystems.com/commons/1888/jun/04/thechannel-islands-the-min-quier-islets

Fleury, C. (2006). Discontinuités et systèmes spatiaux: la combinaison île/frontière à travers les exemples de Jersey, de Saint-Pierre-et-Miquelon et de Trinidad [Discontinuities in spatial systems: the combination of islands and frontiers in the examples of Jersey, Saint-Pierre-etMiquelon and Trinidad]. PhD thesis, Université de Caen Basse-Normandie, Lille, Atelier national de reproduction des thèses.

Fleury, C. (2011). Jersey and Guernsey: two distinct approaches to cross-border fishery management. Shima: The International Journal of Research into Island Cultures, 5(1), 2443.

Fleury, C. (2013). The island/sea/territory relationship: towards a broader and three dimensional view of the aquapelagic assemblage. Shima: The International Journal of Research into Island Cultures, 7(1), 1-13.

Godenau, D. (2012). An institutional approach to bordering in islands: the Canary Islands on the African-European migration routes. Island Studies Journal, 7(1), 3-18.

Godfray, A. D. B. (1929). Archaeological researches at the Minquiers. Société Jersiaise Annual Bulletin, 11(2), 193-199. 


\section{Fleury \& H. Johnson}

Hayward, P. (2012). Aquapelagos and aquapelagic assemblages: towards an integrated study of island societies and marine environments. Shima: The International Journal of Research into Island Cultures, 6(1), 1-11.

Hertslet, L. (Ed.). (1840). A complete collection of the treaties and conventions, and reciprocal regulations, at present subsisting between Great Britain and foreign powers, and of the laws, decrees, and orders in Council, concerning the same; so far as they relate to commerce and navigation; to the repression and abolition of the slave trade; and to the privileges and interests of the subjects of the high contracting parties. London: Henry Butterworth and James Bigg and Son.

International Court of Justice. (1953). The Minquiers and Ecrehos case (France/United Kingdom): Judgement of November $17^{\text {th }}$, 1953. Leiden: A.W. Sijthoff.

King, R. (2009). Geography, islands and migration in an era of global mobility. Island Studies Journal 4(1), 53-84.

Le Courrier des Iles. (2015). Retrieved from http://www.lecourrierdesiles.fr/

'Les Ecrehous' Residents Association. (2015). Retrieved from http://www.ecrehous.com/index.html

Mallison, J. (2011). Les Minquiers: Jersey's southern outpost. Bradford on Avon: Seaflower.

Ramsar. (2015). Retrieved from http://www.ramsar.org/

Rodwell, W. (1986). Saint Mary's Priory, Les Écréhous, Jersey: a reappraisal. Société Jersiaise Annual Bulletin, 24(2), 225-231.

Rodwell, W. (1996). Les Ecréhous, Jersey: the history and archaeology of a Channel Islands archipelago. St Helier, Jersey: Société Jersiaise.

Rybot, N.V.L. (1933). Les Ecrehous: a report on the expedition of 1928 to the islet which is called the Maitre Ile. Société Jersiaise Bulletin Annuel, 12, 178-180.

Secretariat of the Convention on Wetlands, The. (2014). The list of wetlands of international importance, Gland, Switzerland, The Secretariat of the Convention on Wetlands.

Sinsoilliez, R. (1995). Histoire des Minquiers et des Écréhou. Saint-Malo: L'Ancre de Marine.

States of Jersey. (2011a). Jersey's south east coast Ramsar Management Plan. Trinity, Jersey: Department of Planning and Environment.

States of Jersey. (2011b). Tidal power for Jersey: the next steps. Recommendations to the Minister for Planning and Environment from the Tidal Power Commission, St Helier, Jersey: States of Jersey.

States of Jersey. (2012a). Les Écréhous and Les Dirouilles Ramsar Management Plan. Trinity, Jersey: Department of the Environment.

States of Jersey. (2012b). Les Minquiers Ramsar Management Plan. Trinity, Jersey: Department of the Environment.

States of Jersey. (2015). Tidal and wind power: harnessing offshore renewable energy. Retrieved from http://www.gov.je/Environment/GenerateEnergy/Pages/TidalPower.aspx

States of Jersey Planning and Environment Committee. (1999). Jersey Island Plan. Review. countryside character appraisal. Offshore reefs and islands. St Helier, Jersey: States of Jersey Planning and Environment Committee.

Turner, V. (1977). Variations on a theme of liminality. In S. Moore \& B. Myerhoff (Eds.), Secular ritual (pp. 36-52). Assen: Van Gorcum.

United Nations. (1982). United Nations Convention on the Law of the Sea. Montego Bay, Jamaica: United Nations. 